\title{
Analisis Kesuksesan E-Billing pada Kantor Pelayanan Pajak Pratama Palembang Ilir Timur Menggunakan
}

\author{
Rizky Nurfitri Lestari, Rusmala Santi, Irfan Dwi Jaya
}

\begin{abstract}
This study discusses the application of Structural Equation Modeling (SEM) and measures the success of e-billing implementation at the Palembang Ilir Timur Pratama Tax Office and the factors that influence its success. E-billing is developed and managed by the Directorate General of Treasury. There are 100 thousand e-billing users registered at the Palembang Ilir Timur Pratama Tax Office. Based on the analysis results obtained standardized residual covariances matrix values no smaller than -2.58 or greater than 2.58 and the probability of showing a value of 0.080 which means that the value meets the interpretation requirements that the model can be accepted. The results of this study indicate that the success rate of e-billing implementation is at the level of $78 \%$ ("Success"). This needs to be considered by organizations for the development of e-billing in the future.
\end{abstract}

Index Terms - AMOS; Delone and Mclean; EBilling; Structural Equation Modeling (SEM); Success;

Abstrak--Penelitian ini membahas Penerapan Structural Equation Modeling (SEM) dan mengukur kesuksesan implementasi e-billing di Kantor Pelayanan Pajak Pratama Palembang Ilir Timur dan faktor-faktor yang memengaruhi kesuksesannya. $E$-billing dikembangkan dan dikelola oleh Direktorat Jenderal Perbendaharaan. Pengguna e-billing sebanyak 100-an ribu yang terdata pada Kantor Pelayanan Pajak Pratama Palembang Ilir Timur. Berdasarkan hasil analisis didapatkan nilai standardized residual covariances matrix tidak ada yang lebih kecil dari $-2,58$ atau lebih besar dari 2,58 dan probabilitas menunjukan nilai 0,080 yang berarti nilai tersebut memenuhi syarat interpretasi bahwa model dapat diterima. Hasil dari penelitian ini menunjukan bahwa tingkat

Rizky Nurfitri Lestari, Sistem Informasi, Universitas Islam Negeri Raden Fatah Palembang; email: rznurfitri.lestari@gmail.com

Rusmala Santi, Sistem Informasi, Universitas Islam Negeri Raden Fatah Palembang; email: rusmalasanti uin@ radenfatah.ac.id

Irfan Dwi Jaya, Sistem Informasi, Universitas Islam Negeri Raden Fatah Palembang; email: irfan_dj@radenfatah.ac.id kesuksesan implementasi e-billing berada pada tingkat $78 \%$ ("Sukses"). Hal ini perlu dipertimbangkan oleh organisasi untuk pengembangan $e$-billing pada masa depan.

Kata Kunci- AMOS; Delone and Mclean; EBilling; Kesuksesan; Structural Equation Modeling (SEM);

\section{PENDAHULUAN}

Mengenai kesuksesan sistem tidak terlepas dari kemajuan teknologi dalam kearsipan yaitu dengan adanya inovasi pada proses pengarsipan, arsip elektronik. Arsip elektronik ini sudah diterapkan oleh Direktorat Jendral Pajak dalam memudahkan Wajib Pajak untuk membayar pajaknya. Untuk memudahkan Wajib Pajak dalam membayar kewajibannya, Direktorat Jendral Pajak merancang sebuah sistem informasi elektronik bagi Wajib Pajak. Salah satu upaya pemerintah yang dapat dilakukan adalah meningkatkan pelayanan dalam hal pembayaran pajak dengan mengadakan reformasi dan modernsisasi sistem perpajakan. E-billing sendiri merupakan salah satu inovasi dalam hal teknologi informasi. Wajib pajak yang mau membayar kewajiban pajaknya diberi kemudahan akses dengan menggunaakan kode billing tanpa menggunakan Surat Setoran Pajak pada Bank/Pos persepsi, ATM atau internet banking yang ditunjuk oleh Direktorat Jenderal Perbendaharaan.

Berhubungan dengan hal itu Indonesia mengeluarkan Peraturan Menteri Keuangan Republik Indonesia nomor 32/PMK.05/2014 [9]. Diperkuat lagi dari pihak Direktorat Jendral Pajak terakhir mempublikasikan Peraturan Direktur Jenderal Pajak Nomor PER-26/PJ/2014 [8]. Selain itu pada tanggal 1 Juli 2016, Direktorat Jendral Pajak juga sudah mewajibkan wajib pajak menggunakan e-billing dalam transaksi pembayaran pajak.

Mengingat pentingnya penggunaan , penelitian ini merupakan kajian yang menjawab kebutuhan pengembangan $e$-billing ke depan. Dalam penelitian ini akan dibahas analisis tingkat kesuksesan implementasi e-billing, faktor-faktor pendukung kesuksesannya, dan hubungan antarfaktor tersebut.

Hasil penelitian ini berupa informasi terkait tingkat 
kesuksesan implementasi e-billing dan hal-hal yang perlu ditingkatkan. Selain itu, penelitian ini juga memberikan informasi terkait faktor-faktor pendukung kesuksesan implementasi e-billing dan hubungan antarfaktor tersebut. Dengan demikian, hasil penelitian ini akan memudahkan dalam menetapkan arah pengembangan $e$-billing agar tepat sasaran, efisien, ekonomis, efektif dan mendatangkan banyak manfaat.

\section{II.LANDASAN TEORI}

\subsection{Structural Equation Modeling}

SEM dapat dideskripksikan sebagai suatu analisis yang menggabungkan pendekatan analisis faktor (factor analysis), model struktural (structural model), dan analisis jalur (path analysis). Menurut Imam Ghazali [5], SEM merupakan gabungan dari metode statistik terpisah yaitu analisis faktor (factor analysis) serta model persamaan simultan (simultaneous equation modeling).

\subsection{Pengukuran Tingkat Kesuksesan}

Pengukuran tingkat kesuksesan terbagi menjadi 5 tingkat seperti tampak pada Tabel 2.1. Utami dan Samopa mengadopsi model pengukuran tingkat kesuksesan untuk mengukur tingkat kesuksesan Sistem Informasi Akademik [16].

Model ini memberikan pemahaman secara komprehensif tentang keberhasilan sistem informasi dengan mengidentifikasi faktor-faktor pendukung kesuksesan penerapan sistem. Faktor-faktor tersebut adalah information quality, system quality, use, user satisfaction, individual impact, dan organizational impact [2]

Tabel 2.1 Tingkat Kesuksesan

\begin{tabular}{lll}
\hline \hline Tingat & \multicolumn{1}{c}{$\%$} & \\
& \multicolumn{1}{c}{ Kesuksesan } & \\
\hline 1 & $0 \%-20 \%$ & Sangat Tidak Sukses \\
2 & $21 \%-40 \%$ & Tidak Sukses \\
3 & $41 \%-60 \%$ & Cukup Sukses \\
4 & $61 \%-80 \%$ & Sukses \\
5 & $81 \%-100 \%$ & Sangat Sukses \\
& & \\
\hline \hline
\end{tabular}

Hubungan antara dimensi pengukuran ini tampak pada Gambar 2.1. Pada tahun 2003, IS Success Model mengalami perkembangan terkait faktor atau dimensi untuk mengukur kesuksesan penerapan sistem informasi. Dimensi tersebut adalah information quality, system quality, service quality, use, user satisfaction dan net benefit [3].

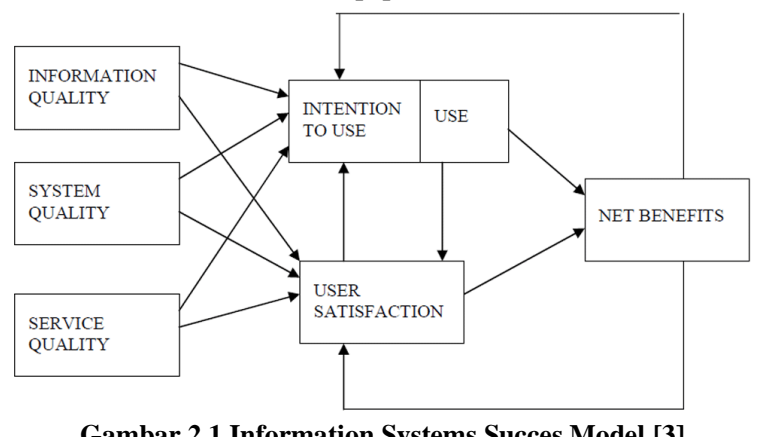

Gambar 2.1 Information Systems Succes Model [3]
Pada Gambar 1 tampak bahwa D\&M IS Success Model memiliki enam dimensi yang saling berhubungan. Detail enam dimensi tersebut adalah:

- System Quality - digunakan untuk mengukur kualitas sistem informasi dari software dan hardware. Kualitas sistem adalah kemampuan perangkat keras, perangkat lunak, kebijakan, prosedur dari sistem informasi untuk menyediakan informasi sesuai kebutuhan pengguna [2]. Kualitas sistem diukur secara subyektif oleh pengguna, sehingga kualitas sistem yang digunakan adalah persepsi kualitas sistem (perceived system quality). Pengukuran kualitas sistem menggunakan indikator-indikator, yaitu; adaptability, availability, reliability, response time, usability, convenience of access, dan system integration.

- Information Quality - digunakan untuk mengukur kualitas keluaran dari sistem informasi [12]. Kualitas informasi ini adalah kualitas informasi yang diukur secara subyektif oleh pengguna atau disebut persepsi kualitas informasi. Pengukuran kualitas informasi menggunakan indikator-indikator, yaitu completeness, ease of understanding, personalization, relevance, security, format of output, currency, dan precision.

- Service Quality - merupakan perbandingan antara harapan pengguna dengan layanan diterima. Terdapat tiga komponen yang memengaruhi kualitas layanan (service quality), yaitu jaminan (assurance) kualitas yang diberikan sistem, kepedulian sistem (system empathy) terhadap pengguna, system responsiveness yaitu kualitas respon sistem terhadap permintaan pengguna [3]. Pengukuran kualitas layanan menggunakan indikator-indikator, yaitu assurance, empathy dan responsiveness.

- Use - dibedakan untuk penggunaan keluaran (information use) dan penggunaan sistem (system use) [12]. Pengukuran use dengan indikator-indikator, yaitu nature of use, navigation patterns, number of site visits, number of transactions executed.

- User Satisfaction - merupakan respon dan umpan balik dari pengguna setelah memakai sistem informasi. Sikap pengguna terhadap sistem informasi merupakan kriteria subjektif mengenai tingkat kepuasan pengguna terhadap sistem. Pengukuran kepuasan pengguna menggunakan indikator-indikator, yaitu repeat purchases, repeat visits, user surveys[3]

- Net Benefit - adalah hasil bersih atau keuntungan yang dirasakan oleh individu dan juga organisasi setelah menerapkan sistem informasi. Pengukuran net benefit menggunakan indikatorindikator, yaitu; cost savings, expanded markets, incremental additional sales, reduced search costs, tim saving, ease of job, effectiveness, speeds of accomplishing task, usefullness in work [4].

\subsection{Kerangka Pemikiran dan Hipotesis}

IS Success Model Delone dan McLean telah digunakan banyak peneliti untuk mengukur kesuksesan implementasi sistem informasi [7]. Hasil penelitian mereka di antaranya kualitas informasi secara signifikan memengaruhi kepuasan pengguna. Kesuksesan sistem informasi dipengaruhi oleh kualitas sistem informasi 
dan kualitas informasi [6]. Penambahan kualitas layanan membawa perubahan dalam penggunaan IS success model, terutama pengembangan fenomenal pada ecommerce [10].

Berdasarkan penelitian sebelumnya, maka kerangka pemikiran artikel ini adalah tampak pada Gambar 2.2.

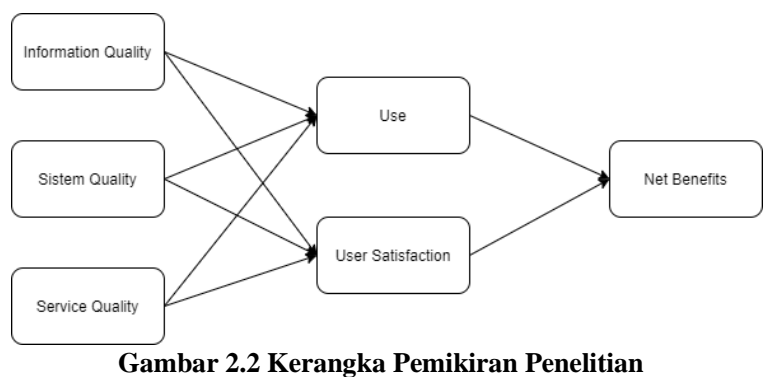

Kerangka pemikiran penelitian ini mendasari penyusunan kuesioner hasil modifikasi [3].

Berdasarkan hasil penelitian sebelumnya, maka hipotesis penelitian ini adalah:

1. $H_{0}:$ Kualitas sistem berpengaruh signifikan terhadap Penggunaan sistem $e$-billing.

$H_{a}:$ Kualitas sistem tidak berpengaruh signifikan terhadap Penggunaan sistem $e$-billing.

2. $H_{0}:$ Kualitas Sistem berpengaruh signifikan terhadap Kepuasan Pemakai sistem e-billing.

$H_{a}$ : Kualitas Sistem tidak berpengaruh signifikan terhadap Kepuasan Pemakai sistem $e$-billing.

3. $H_{0}:$ Kualitas Informasi berpengaruh signifikan terhadap Penggunaan sistem $e$-billing.

$H_{a}$ : Kualitas Informasi tidak berpengaruh signifikan terhadap Penggunaan sistem $e$-billing .

4. $H_{0}$ : Kualitas Informasi berpengaruh signifikan terhadap Kepuasan Pemakai sistem e-billing.

$H_{a}$ : Kualitas Informasi tidak berpengaruh signifikan terhadap Kepuasan Pemakai sistem $e$ billing.

5. $H_{0}:$ Kualitas Pelayanan berpengaruh signifikan terhadap Penggunaan sistem $e$-billing .

$H_{a}$ : Kualitas Pelayanan tidak berpengaruh signifikan terhadap Penggunaan sistem $e$-billing.

6. $H_{0}:$ Kualitas Pelayanan berpengaruh signifikan terhadap Kepuasan Pemakai sistem e-billing.

$H_{a}$ : Kualitas Pelayanan tidak berpengaruh signifikan Kepuasan Pemakai sistem e-billing.

7. $H_{0}$ : Penggunaan berpengaruh signifikan terhadap Manfaat-manfaat bersih sistem $e$-billing.

$H_{a}$ : Penggunaan tidak berpengaruh signifikan terhadap Manfaat-manfaat bersih sistem $e$-billing .

8. $H_{0}:$ Kepuasan Pemakai berpengaruh signifikan terhadap Manfaat-manfaat bersih sistem $e$-billing.

$H_{a}$ : Kepuasan Pemakai tidak berpengaruh signifikan terhadap Manfaat-manfaat bersih sistem e-billing.

\section{METODE PENELITIAN}

\subsection{Variabel Penelitian}

\subsubsection{Variabel Independen}

Variabel independen adalah variabel yang mempengaruhi atau yang menjadi sebab perubahannya atau timbulnya variabel dependen (terikat)[17]. Variabel independen atau eksogen dalam model kesuksesan sistem informasi adalah:

- System Quality (SQ) - adalah kualitas sistem informasi yang merupakan kemampuan perangkat keras, perangkat lunak, kebijakan, prosedur dari sistem informasi untuk menyediakan informasi sesuai kebutuhan pengguna.

- Information Quality (IQ) - adalah kualitas informasi yang diukur secara subyektif oleh pengguna atau disebut sebagai persepsi kualitas informasi.

- Service Quality (SEQ) - adalah kualitas layanan yang merupakan perbandingan antara harapan pengguna dengan layanan yang diterimanya.

\subsubsection{Variabel Dependen}

Variabel dependen adalah variabel dipengaruhi oleh variabel independen. Variabel dependen atau endogen dalam model kesuksesan sistem informasi adalah:

- User Satisfaction (US) - adalah kepuasan dari pengguna OM SPAN atas aplikasi dan outputnya.

- Use (UI) - adalah penggunaan OM SPAN oleh pengguna akhir atas kesadaran dan keinginannya sendiri. - Net Benefit (NB) - adalah manfaat bersih atau keutungan yang dirasakan oleh individu dan juga organisasi setelah menerapkan sistem informasi.

\subsection{Metode Pengumpulan Data}

Pengumpulan data penelitian ini menggunakan metode survei dengan instrumen penelitian berupa kuesioner. Kuesioner tersebut merupakan modifikasi dan pengembangan penelitian [2]. Kuesioner penelitian ini menggunakan skala Likert untuk mengukur persepsi responden terhadap indikator. Skala Likert terdiri dari lima tingkat preferensi jawaban yaitu; Sangat tidak setuju (1), Tidak Setuju (2), Netral (3), Setuju (4) dan Sangat Setuju (5). Selanjutnya, kuesioner berserta petunjuk pengisiannya dibagikan kepada pengguna $e$ billing.

\subsection{Metode Analisis Data}

Metode analisis data yang digunakan adalah SEM. Menurut Bacon [1] kelebihan menggunakan SEM adalah:

a. SEM memberikan pengamatan yang lebih luas terhadap hubungan variabel laten dan variabel lainnya. Dengan menggunakan SEM dapat memodelkan variabel laten dengan beberapa variabel indikator penting dan melihat keandalan masing-masing indikatornya.

b. SEM lebih andal untuk menguraikan dan menganalisis setiap bagian yang dikembangkan sebuah model persamaan. Sedangkan analisis jalur dan regresi 
berganda hanya menjangkau bagian terluar dari sebuah model penelitian.

c. SEM mampu mengatasi data yang sulit, seperti data time series dengan kesalahan autokorelasi, data tidak tirdistribusi normal, dan data tidak lengkap. Dalam analisis menggunakan regresi berganda penanganan uji asumsi klasik (normalitas data, autokorelasi, multikolonieritas dan heteroske-dastisitas) sulit dilakukan jika sudah melibatkan variabel moderating atau intervening.

Ghozali [5] mengajukan tahapan pemodelan dan analisis persamaan struktural menjadi tujuh langkah yaitu : (1) pengembangan model secara teoritis, (2) menyusun diagram jalur (path diagram), (3) mengubah diagram jalur menjadi persamaan struktural, (4) memilih matrik input untuk analisis data, (5) menilai identifikasi model, (6) mengevaluasi estimasi model, (7) interpretasi terhadap model. Berikut ini dijelaskan masing-masing tahapan.

1. Langkah pertama : Pengembangan model berdasarkan teori

Model persamaan struktural didasarkan pada hubungan kausalitas, dimana perubahan satu variabel diasumsikan akan berakibat pada perubahan variabel lainnya. Kuatnya hubungan kausalitas antara dua variabel yang diasumsikan oleh peneliti bukan terletak pada metode analisis yang dia pilih, tetapi terletak pada justifikasi (pembenaran) secara teoritis untuk mendukung analisis. Jadi hubungan antar variabel dalam model merupakan deduksi dari teori.

2. Langkah kedua dan ketiga : menyusun diagram jalur dan persamaan struktural.

Menyusun hubungan kausalitas dengan diagram jalur dan menyusun persamaan strukturalnya. Ada dua cara yang harus dilakukan yaitu (1) menyusun model struktural yaitu menghubungkan antar konstruk laten baik endogen maupun eksogen, (2) menyusun measurement model yaitu menghubungkan konstruk laten endogen atau eksogen dengan variabel indikator atau manifest. Ketika measurement model telah terspesifikasi, peneliti menentukan reliabilitas dari indikator dengan dua cara yaitu (1) diestimasi secara empiris, (2) dispesifikasi.

3. Langkah keempat : memilih input matrik dan estimasi model yang diusulkan

SEM hanya menggunakan data input berupa matrik varian atau kovarian atau matrik korelasi. AMOS akan merubah dahulu data mentah menjadi matrik kovarian atau matrik korelasi. Analisis terhadap data outlier harus dilakukan sebelum matrik kovarian atau korelasi dihitung. Jadi dapat disimpulkan peneliti harus menggunakan input matrik varian atau kovarian untuk menguji teori. Jika peneliti hanya ingin melihat pola hubungan dan tidak melihat total penjelasan yang diperlukan dalam uji teori, maka penggunaan matrik korelasi diterima.

4. Langkah kelima : menilai identifikasi model

Problem identifikasi adalah ketidak mampuan proposed model untuk menghasilkan unique estimate. Cara melihat ada tidaknya problem identifikasi adalah dengan melihat hasil estimasi yang meliputi (1) adanya standar nilai error yang besar untuk satu atau lebih koefiesien, (2) ketidak mampuan program untuk invert information matrix, (3) nilai estimasi yang tidak mungkin misalkan error variance yang negative, (4) adanya nilai korelasi yang tinggi $(>0,90)$ antar koefisien estimasi. Jika diketahui ada ada problem identifikasi maka ada tiga hal yang harus dilihat : (1) besarnya jumlah koefisien yang diestimasi relatif terhadap jumlah kovarian atau korelasi, yang diindikasikan dengan nilai degree of freedom yang kecil, (2) digunakannya pengaruh timbalbalik atau resiprokal antar konstruk (model nontecursive) atau (3) kegagalan dalam menetapkan nilai tetap (fix) pada skala konstruk.

5. Langkah keenam : menilai kriteria Goodness-ofFit

Langkah yang harus dilakukan sebelum menilai kelayakan dari model struktural adalah menilai apakah data yang akan diolah memenuhi asumsimodel persamaan struktural. Langkah berikutnya adalah melihat ada tidaknya offending estimate yaitu estimasi koefisien baik dalam model sruktural maupun model pengukuran yang nilainya diatas batas yang dapat diterima. Setelah yakin tidak ada lagi offending estimate dalam model, maka peneliti siap melakukan penilaian overall model fit dengan berbagai kriteria penilaian model fit. Ada tiga jenis ukuran Goodness-of-Fit yaitu (1) Absolute Fit Measure, (2) Incremental Fit Measures dan (3) Parsimonious Fit Measures.

6. Langkah ketujuh : interpretasi dan modifikasi model

Ketika model telah dinyatakan diterima, maka peneliti dapat mempertimbangkan dilakukannya modifikasi model untuk memperbaiki penjelasan teoritis atau Goodness-of-Fit. Jika model dimodifikasi, maka model tersebut harus di crossvalidited (diestimasi dengan data terpisah) sebelum model modifikasi diterima.

\section{HASIL DAN PEMBAHASAN}

\subsection{Analisis Pengukuran Kesuksesan}

Pengukuran tingkat kesuksesan menggunakan kuesioner dengan skala 1-5. Hasil pengkuruan kesuksesan implementasi e-billing. Berdasarkan hasil pengukuran tersebut, rata-rata item pengukuran sebesar 3,93 pada skala 1-5. Selanjutnya, persentase tingkat kesuksesan didapatkan 78\% $\quad(3,93 / 5 \quad \mathrm{x}$ $100 \%)$. Berdasarkan Purwanto [11] nilai $78 \%$ menunjukkan bahwa implementasi e-billing pada tingkat "Sukses".

4.2 Analisis Model

\subsubsection{Uji validitas}

Uji validitas menggunakan AMOS versi 21, dengan acuan nilai loading factor lebih dari 0.5. Hasilnya, satu variabel dihapus dari model yaitu: SQ1 atau X1_1 dikarenakan nilai loading factor kurang dari 0.5. 
Tabel 4.1. Assesment of Normality

\begin{tabular}{|c|c|c|c|c|c|c|}
\hline $\begin{array}{c}\text { ariabl } \\
\mathrm{e}\end{array}$ & $\min$ & $\max$ & skew & c.r. & $\begin{array}{c}\text { kurtosi } \\
\text { S }\end{array}$ & c.r. \\
\hline X1 6 & 2,000 & 5,000 & -869 & $-4,123$ & .748 & 1,775 \\
\hline Z_ 5 & 1,000 & 5,000 &,- 284 & $-1,346$ & 079 &, 188 \\
\hline Z_4 & 1,000 & 5,000 &,- 586 & $-2,781$ & 697 & 1,654 \\
\hline Z_3 & 1,000 & 5,000 &,- 201 &,- 954 &,- 536 & $-1,271$ \\
\hline Z_2 & 1,000 & 5,000 &,- 514 & $-2,436$ & ,000 &, 000 \\
\hline Z_1 & 1,000 & 5,000 &,- 257 & $-1,217$ &,- 453 & $-1,075$ \\
\hline$Y \overline{2} \_1$ & 2,000 & 5,000 &,- 152 &,- 720 &,- 715 & $-1,695$ \\
\hline$Y 2 \_2$ & 2,000 & 5,000 &,- 342 & $-1,620$ &,- 661 & $-1,688$ \\
\hline$Y 1 \_2$ & 1,000 & 5,000 &,- 400 & $-1,900$ &,- 573 & $-, 1,359$ \\
\hline$Y 1 \_1$ & 1,000 & 5,000 &,- 393 & $-1,862$ & -295 & 6,89 \\
\hline$X 3 \_1$ & 2,000 & 5,000 &,- 851 & $-4,037$ & ,007 & 017 \\
\hline$X 3 \_2$ & 1,000 & 5,000 &,- 822 & $-3,898$ & ,291 & 689 \\
\hline$X 3 \_3$ & 1,000 & 5,000 &,- 660 & $-3,130$ & ,323 &,- 765 \\
\hline$X 2 \_1$ & 2,000 & 5,000 &,- 586 & $-2,684$ &,- 100 &,- 236 \\
\hline$X 2 \_2$ & 2,000 & 5,000 &,- 371 & $-1,761$ &,- 122 & -290 \\
\hline$X 2 \_3$ & 2,000 & 5,000 &,- 246 & $-1,165$ &,- 723 & $-1,715$ \\
\hline$X 2 \_4$ & 2,000 & 5,000 &,- 542 & $-2,570$ &, 146 &, 346 \\
\hline$X 2 \_5$ & 1,000 & 5,000 &,- 803 & $-3,810$ & 1,023 & 2,427 \\
\hline$X 1 \_2$ & 2,000 & 5,000 &,- 668 & $-3,168$ &, 112 & 266 \\
\hline$X 1 \_3$ & 3,000 & 5,000 &,- 278 & $-1,320$ & $-1,041$ & -2.469 \\
\hline$X 1 \_4$ & 2,000 & 5,000 &,- 685 & $-3,247$ & ,295 & 699 \\
\hline$X 1-5$ & 2,000 & 6,000 &,- 493 & $-2,341$ &, 596 & 1,413 \\
\hline $\begin{array}{l}\text { Multi } \\
\text { variat }\end{array}$ & & & & & 21.701 & \\
\hline
\end{tabular}

\subsubsection{Uji Normalitas}

Uji normalitas menggunakan AMOS versi 21, tampak dengan nilai kritikal (c.r.) antara -2.58 s.d 2.58. Hasilnya, data terdistribusi tidak normal tampak pada nilai c.r. di luar range -2.58 s.d 2.58 .

\subsubsection{Uji model menggunakan SEM-AMOS}

Tujuan utama dalam persamaan struktural yaitu untuk mengetahui seberapa jauh model yang dihipotesakan "fit" atau cocok dengan sampel data. Berikut tampilan model awal setelah di estimasi:

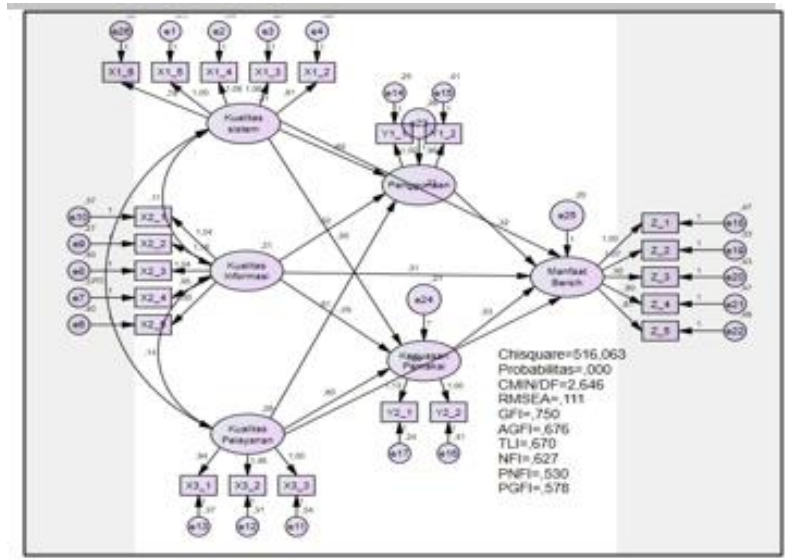

Gambar 4.1 Model Awal

Berdasarkan komputasi AMOS 22, untuk model awal ini dihasilkan indeks-indeks Goodness Of Fit sebagaimana pada tabel 4.2 .

Tabel 4.2 Hasil Uji Model Awal

\begin{tabular}{ccll}
\hline \hline $\begin{array}{c}\text { Goodness of } \\
\text { Fit Indices }\end{array}$ & $\begin{array}{c}\text { Cut }- \text { Off } \\
\text { Value }\end{array}$ & $\begin{array}{l}\text { Hasil Uji } \\
\text { Model }\end{array}$ & Keterangan \\
\hline Chi_Square & $\begin{array}{l}\text { Diharapkan } \\
\text { kecil }\end{array}$ & 576,063 & Poor Fit \\
Probabilitas & $>0,05$ & 0,000 & Poor Fit \\
RMSEA & $\leq 0,08$ & 0,111 & Poor Fit
\end{tabular}

\begin{tabular}{llll} 
GFI & $>0.90$ & 0,750 & Poor Fit \\
AGFI & $\geq 0,090$ & 2,646 & Poor Fit \\
& & & \\
CMINDF & $<2$ & 0,670 & Poor Fit \\
TLI & $\geq 0,090$ & 0,627 & Poor Fit \\
NFI & $\geq 0,090$ & 0,527 & Poor Fit \\
PNFI & $0,60-0,90$ & 0,530 & Marginal \\
& (Semakin & & \\
& tinggi & & \\
& semakin & & \\
PGFI & baik) & 0,578 & \\
& $0-1$ & & \\
& (Semakin & & \\
& tinggi & & \\
& semakin & & \\
& baik) & & \\
& & & \\
\hline \hline
\end{tabular}

Tabel 4.2 menunjukkan bahwa hampir seluruh Goodness Of Fit Indices menunjukkan nilai yang tidak baik. Oleh karena itu dapat ditarik kesimpulan bahwa model dinyatakan belum baik atau belum memenuhi syarat pengujian.

\subsubsection{Interpretasi Terhadap Model}

Langkah ini adalah untuk memutuskan bentuk perlakuan lanjutan setelah dilakukan evaluasi asumsi dan uji kesesuaian pada model awal. Jika model dinyatakan baik, maka langkah berikutny-,720a adalah melakukan interpretasi. Namun jika model dinyatakan belum baik atau tidak memenuhi syarat pengujian, maka perlu diadakan modifikasi. Setelah model diestimasi, residualnya haruslah kecil atau mendekati nol dan distribusi frekuensi dari kovarians residual harus bersifat simetrik.

Gambar 4.2memperlihatkan bahwa hampir separuh Goodness Of Fit Indices menunjukkan nilai yang tidak baik dan separuhnya lagi menunjukkan nilai yang cukup baik. Oleh karena itu perlu dilakukan modifikasi agar Goodness Of Fit Indices memenuhi syarat pengujian dan model dapat diterima dengan baik. Modifikasi dilakukan dengan melihat nilai modification index (MI) pada modification indices yang terdapat pada output AMOS, dimana peneliti mengkovariankan error dengan melihat nilai MI yang paling besar, kemudian dilakukan estimasi ulang. Hal ini terus dilakukan hingga Goodness Of Fit Indices menunjukkan nilai yang memenuhi syarat pengujian (Cut-Off Value) dan model dapat dinyatakan fit. Model yang telah dimodifikasi dapat dilihat pada gambar 4.2

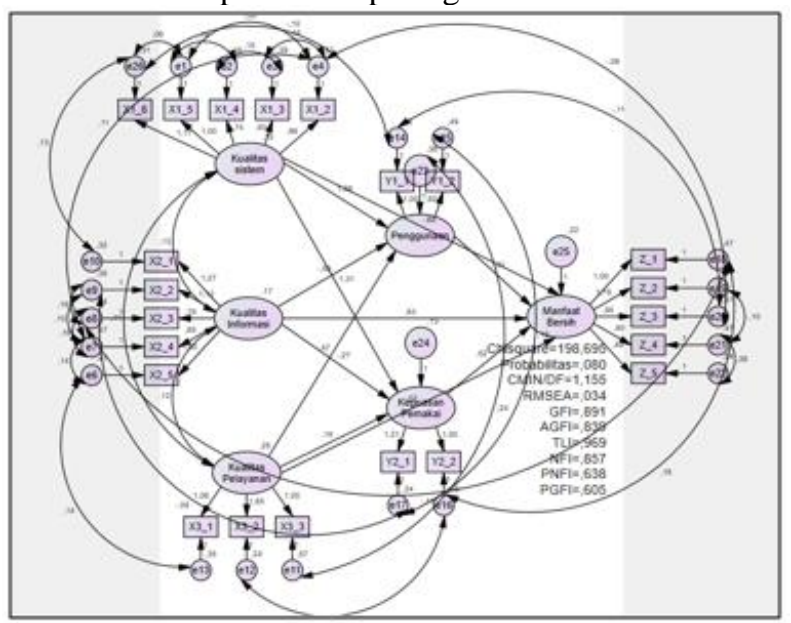

Gambar 4.2 Model Setelah Modifikasi 
Setelah model awal dimodifikasi diperoleh nilai Goodness Of Fit Indices yang memenuhi syarat pengujian. Berdasarkan komputasi AMOS 22, untuk model yang telah dimodifikasi dihasilkan indeks-indeks Goodness Of Fit yang dapat dilihat pada tabel 4.3

Tabel 4.3 Hasil Uji Model Setelah Modifikasi

\begin{tabular}{llll}
\hline $\begin{array}{c}\text { Goodness of } \\
\text { Fit Indices }\end{array}$ & \multicolumn{1}{c}{$\begin{array}{c}\text { Cut }- \text { Off } \\
\text { Value }\end{array}$} & $\begin{array}{l}\text { Hasil Uji } \\
\text { Model }\end{array}$ & Keterangan \\
\hline Chi_Square & $\begin{array}{l}\text { Diharapkan } \\
\text { kecil }\end{array}$ & 198,696 & Good Fit \\
Probabilitas & $>0,05$ & 0,080 & Good Fit \\
RMSEA & $\leq 0,08$ & 0,034 & Good Fit \\
GFI & $>0.90$ & 0,891 & Good Fit \\
AGFI & $\geq 0,09$ & 0,839 & Good Fit \\
& & & \\
CMINDF & $<2$ & 1,155 & Good Fit \\
TLI & $\geq 0,09$ & 0,969 & Good Fit \\
NFI & $\geq 0,09$ & 0,857 & Good Fit \\
PNFI & $0,60-0,90$ & 0,638 & \\
& (Semakin & & \\
& tinggi & & Good Fit \\
PGFI & semakin baik) & & \\
& $0-1$ & 0,605 & \\
& (Semakin & & \\
\hline \hline
\end{tabular}

Untuk memberikan interpretasi bahwa model dapat diterima, peneliti jugaperlu mengamati besarnya residual yang dihasilkan. Apabila pada standardized residual covariances matrix nilai berada pada ring $-2,58$ $\leq$ standardized residual $\geq 2,58$ dan probabilitas $>0,05$ maka model dapat diterima. Setelah model di modifikasi, nilai standardized residual covariances matrix tidak ada yang lebih kecil dari $-2,58$ atau yang lebih besar dari 2,58 dan probabilitas menunjukkan nilai 0,080 yang berarti nilai tersebut memenuhi syarat interpretasi bahwa model dapat diterima.

Setelah semua asumsi dapat dipenuhi, selanjutnya akan dilakukan pengujian hipotesis. Pengujian hipotesis penelitian ini dilakukan dengan melihat nilai CR dan nilai $\mathrm{P}$ pada regression weights sebagaimana nilai $\mathrm{CR}$ menunjukkan nilai critical ratio yang didapatkan dari nilai estimasi yang dibagi oleh standar error-nya (S.E). Semakin tinggi nilai CR semakin signifikan. Nilai CR dan $\mathrm{P}$ yang diisyaratkan yaitu $>1,96$ untuk nilai $\mathrm{CR}$ dan $<0,05$ untuk nilai P. Bila hasil proses output menunjukkan nilai yang memenuhi persyaratan maka hipotesis penelitian dapat diterima [5]. Uji hipotesis dalam penelitian ini dapat dilihat pada tabel 4.5

\section{Tabel 4.5. Uji Hipotesis}

\begin{tabular}{|c|c|c|c|}
\hline & C.R & $\mathrm{P}$ & Ket \\
\hline Penggunaan $\leftarrow$ Kualitas_Sistem & 1,634 & 102 & Ditolak \\
\hline $\begin{array}{l}\text { Kepuasan_Pemakai } \leftarrow \\
\text { Kualitas_Sistem }\end{array}$ & 2,121 & 034 & Diterima \\
\hline $\begin{array}{l}\text { Penggunaan } \leftarrow \\
\text { Kualitas_Informasi }\end{array}$ &,- 718 & ,473 & Ditolak \\
\hline $\begin{array}{l}\text { Kepuasan_Pemakai } \leftarrow \\
\text { Kualitas_Informasi }\end{array}$ &,- 522 & ,602 & Ditolak \\
\hline $\begin{array}{l}\text { Penggunaan } \leftarrow \\
\text { Kualitas_Pelayanan }\end{array}$ & 1,991 &, 046 & Diterima \\
\hline $\begin{array}{l}\text { Kepuasan_Pemakai } \leftarrow \\
\text { Kualitas_Pelayanan }\end{array}$ & ,926 & ,337 & Ditolak \\
\hline $\begin{array}{l}\text { Manfaat_Bersih } \leftarrow \\
\text { Kepuasan_Pemakai }\end{array}$ & 1,991 & ,046 & Diterima \\
\hline Manfaat_Bersih $\leftarrow$ Penggunaan & 2,20 &, 027 & Diterima \\
\hline
\end{tabular}

Berdasarkan tabel 5, Hipotesis 2,5,7,8 diterima dan yang lainnya ditolak.

\subsection{Pembahasan}

Hasil pengukuran kesuksesan implementasi e-billing pada tingkat $78 \%$. Berdasarkan Purwanto[11]tingkat tersebut temasuk pada tingkat "Sukses". Kesuksesan implementasi e-billing pada tingkat "Sukses" ini didukung oleh beberapa faktor. Faktor-faktor pendukung tersebut adalah kualitas informasi, kualitas sistem, kualitas pelayanan, kepuasan pengguna dan manfaat bersih yang diterima pengguna.

Penelitian ini menerapkan model SEM atau model analisis jalur untuk pembuktian hipotesis penelitian. Perhitungan statistik dalam analisis jalur atas variabel yang digunakan dalam penelitian ini adalah dengan menggunakan bantuan program komputer AMOS versi 22. Penerapan model SEM dipilih karna dalam model penelitian terdapat variabel intervening, yaitu penggunan dan kepuasan pemakai yang menghubungkan antara kualitas sistem, kualitas informasi dan kualitas pelayanan dengan manfaat bersih yang diterima. Menurut Ghozali [5], hubungan tidak langsung (indirect effect) akan lebih sulit dianalisis jika menggunakan analisis regresi berganda. Uji terhadap kelayakan full model SEM ini diuji dengan menggunakan Chi square dan RMSEA sebagaimana yang dijelaskan dalam tabel 4.6 dibawah ini:

Tabel 4.6. Goodness of Fit Model

\begin{tabular}{llll}
\hline \hline $\begin{array}{c}\text { Goodness of } \\
\text { Fit Indices }\end{array}$ & $\begin{array}{c}\text { Cut }- \text { Off } \\
\text { Value }\end{array}$ & Hasil & $\begin{array}{l}\text { Evaluasi } \\
\text { Model }\end{array}$ \\
\hline Chi_Square & $\begin{array}{l}\text { Diharapkan } \\
\text { Kecil }\end{array}$ & 198,895 & Baik \\
Probabilitas & $\geq 0,05$ & 0,080 & Baik \\
RMSEA & $\leq 0,08$ & 0,034 & Baik
\end{tabular}

Nilai chi-square sebesar 198,695 dengan tingkat signifikansi sebesar 0,080 menunjukkan bahwa model yang digunakan dapat diterima dengan baik. Hal tersebut didasarkan pada kriteria dimana nilai signifikansi probabilitas yang lebih besar dari 0,05 mengindikasikan model tersebut merupakan model yang baik. Hasil penelitian menunjukkan bahwa variabelvariabel penelitian yang terdiri dari kualitas informasi, kualitas sistem, kualitas pelayanan, penggunaan, kepuasan pemakai dan manfaat yang diterima perusahaan maka hubungan antara faktor-faktor pendukung kesuksesan sistem $e$-billing adalah:

1) Pengaruh kualitas sistem terhadap penggunaan dan manfaat-manfaat bersih bagi pengguna. Hasil pengujian dan analisis data menunjukkan bahwa kualitas sistem secara langsung tidak berpengaruh signifikan terhadap penggunaan. Hal ini berarti bahwa hipotesis 1 ditolak. Hasil penelitian ini berbeda dengan Livari [6] dalam M. Ichsan [7]

Selain itu, kualitas sistem secara tidak langsung berpengaruh signifikan terhadap manfaat bersih bagi 
pengguna. Hasil penelitian ini sesuai denganLivari [6] dalam M. Ichsan [7].

Hasil pengukuran kualitas sistem berdasarkan Purwanto [11] menunjukkan nilai baik dengan rata-rata 3,35 dari skala 1-5. Hal ini mendukung kesuksesan implementasi e-billing. Namun demikian, jika kualitas sistem ini ditingkatkan akan memberikan dampak pada peningkatan pengguna dan manfaat bersih yang diterimanya.

2) Pengaruh kualitas sistem terhadap kepuasan pengguna. Hasil pengujian dan analisis data menunjukkan bahwa kualitas sistem secara langsung berpengaruh signifikan terhadap penggunaan. Hal ini berarti bahwa hipotesis 2 diterima. Hasil penelitian ini sesuai dengan Livari [6] dalam M. Ichsan [7].

Hasil pengukuran kualitas sistem berdasarkan Purwanto [11] menunjukkan nilai baik dengan rata-rata 3,35 dari skala 1-5. Hal ini mendukung kesuksesan implementasi e-billing. Namun demikian, jika kualitas sistem ini ditingkatkan akan memberikan dampak pada peningkatan kepuasan pemakai.

3) Pengaruh kualitas informasi terhadap penggunaan. Hasil pengujian dan analisis data menunjukkan bahwa kualitas informasi secara langsung tidak berpengaruh signifikan terhadap penggunaan. Hal ini berarti bahwa hipotesis 3 ditolak. Hasil penelitian ini berbeda denganLivari [6] dalam $\mathrm{M}$. Ichsan [7].

4) Pengaruh kualitas informasi terhadap kepuasan pemakai. Hasil pengujian dan analisis data menunjukkan bahwa kualitas informasi secara langsung tidak berpengaruh signifikan terhadap kepuasan pemakai . Hal ini berarti bahwa hipotesis 4 ditolak. Hasil penelitian ini berbeda dengan yang dilakukan oleh Livari [6].

Selain itu, kualitas informasi secara tidak langsung juga tidak berpengaruh signifikan terhadap manfaat bersih. Hal ini berarti bahwa hipotesis 4 ditolak. Hasil penelitian ini berbeda dengan Livari [6] dalam $\mathrm{M}$. Ichsan [7].

Hasil pengukuran kualitas informasi berdasarkan Purwanto [11] menunjukkan nilai baik dengan rata-rata 4,00 dari skala 1-5. Hal ini mendukung kesuksesan implementasi e-billing. Namun demikian, jika kualitas informasi ini ditingkatkan akan memberikan dampak pada peningkatan penggunaan, kepuasan pemakai dan manfaat bersih.

5) Pengaruh kualitas pelayanan berpengaruh terhadap penggunaan. Hasil pengujian dan analisis data menunjukkan bahwa kualitas pelayanan secara langsung berpengaruh signifikan terhadap penggunaan. Hal ini berarti bahwa hipotesis 5 diterima. Hasil penelitian ini berbeda dengan sedera [14] dengan peter [10] dalam M.Ichsan [7]
6) Pengaruh kualitas pelayanan terhadap kepuasan pemakai. Hasil pengujian dan analisis data menunjukkan bahwa pelayanan secara langsung tidak berpengaruh signifikan terhadap kepuasan pemakai . Hal ini berarti bahwa hipotesis 6 ditolak. Hasil penelitian ini sesuai dengan sedera [14] dengan peter [10] dalam M.Ichsan [7].

Selain itu, kualitas pelayanan secara tidak langsung juga berpengaruh signifikan terhadap manfaat bersih. Hasil penelitian ini berbeda dengan Livari [6] dalam M. Ichsan [7].

Hasil pengukuran kualitas pelayanan berdasarkan Purwanto [11] menunjukkan nilai baik dengan rata-rata 4,04 dari skala 1-5. Hal ini mendukung kesuksesan implementasi $e$-billing. Namun demikian, jika kualitas pelayanan ini ditingkatkan akan memberikan dampak pada peningkatan penggunaan, kepuasan pemakai dan manfaat bersih.

1) Pengaruh penggunaan terhadap manfaat bersih. Hasil pengujian dan analisis data menunjukkan bahwa penggunaan secara langsung berpengaruh signifikan terhadap manfaat bersih. Hal ini berarti bahwa hipotesis 7 diterima. Hasil penelitian ini berbeda dengan sedera [14] dengan peter [10] dalam M.Ichsan [7].

2) Hasil pengukuran penggunaan berdasarkan Purwanto [11]menunjukkan nilai baik dengan rata-rata 3,80 dari skala 1-5. Hal ini mendukung kesuksesan implementasi e-billing. Pengaruh kepuasan pemakai terhadap manfaat bersih. Hasil pengujian dan analisis data menunjukkan bahwa penggunaan secara langsung berpengaruh signifikan terhadap manfaat bersih. Hal ini berarti bahwa hipotesis 8 diterima. Hasil penelitian ini sesuai denganLivari [6] dalam M. Ichsan [7]. Hasil pengukuran kepuasan pemakai berdasarkan Purwanto [11] menunjukkan nilai baik dengan rata-rata 3,74 dari skala 1-5. Hal ini mendukung kesuksesan implementasi e-billing. Hasil ini menunjukkan bahwa kepuasan pemakai yang didapatkan dari kualitas informasi, kualitas sistem dan kualitan pelayanan memiliki peran penting pada manfaat yang diterima. Peningkatan yang terjadi pada kepuasan pemakai akan berdampak pada peningkatan manfaat yang diterimanya.

\section{V.KESIMPULAN}

Setelah dilakukan penelitian mengenai Analisis kesuksesan sistem e-billing pada Kantor Pelayanan Pajak Pratama Palembang Ilir Timur menggunakan SEM maka dapat ditarik kesimpulan sebagai berikut: Dari penerapan model SEM didapatkan nilai standardized residual covariances matrix tidak ada yang lebih kecil dari -2,58 atau lebih besar dari 2,58 dan probabilitas menunjukan nilai 0,080 yang berarti nilai tersebut memenuhi syarat interpretasi bahwa model dapat diterima. Hasil pengukuran kesuksesan implementasi sistem e-billing pada tingkat $78 \%$. Berdasarkan Purwanto [11] tingkat tersebut temasuk pada tingkat "Sukses". Kesuksesan implementasi sistem e-billing pada tingkat "Sukses". Selanjutnya, tingkat kesuksesan sistem e-billing didukung oleh beberapa faktor yaitu bahwa Kualitas Sistem berpengaruh signifikan terhadap Kepuasan Pemakai hal ini 
ditunjukkan dengan nilai $\mathrm{CR}=2,035 \mathrm{dan}$ Probabilitas $=$ 0,042, Kualitas Pelayanan berpengaruh signifikan terhadap Penggunaan hal ini ditunjukkan dengan nilai $\mathrm{CR}=2,155 \mathrm{dan} \quad$ Probabilitas $=0,031$, Penggunaan berpengaruh signifikan terhadap Manfaat-manfaat Bersih hal ini ditunjukkan dengan nilai $\mathrm{CR}=2,793$ dan Probabilitas $=0,005$, dan Kepuasan Pemakai berpengaruh signifikan terhadap Manfaat-manfaat Bersih hal ini ditunjukkan dengan nilai $\mathrm{CR}=3$,778dan Probabilitas $=* * *$ yang berarti semakin tinggi kualitas sistem maka akan semakin tinggi juga kepuasan pemakai. Kualitas Pelayanan juga berpengaruh terhadap penggunaan sistem $E$-Billing. Adapun faktor yang tidak mempengaruhi kesuksesan sistem e-billing yaitu Kualitas Informasi tidak berpengaruh signifikan terhadap Penggunaan hal ini ditunjukkan dengan nilai $\mathrm{CR}=-0,551 \mathrm{dan} \quad$ Probabilitas $=0,581$, Kualitas Informasi tidak berpengaruh signifikan terhadap Kepuasan Pemakai hal ini ditunjukkan dengan nilai CR $=0,419 \mathrm{dan}$ Probabilitas = 0,675, Kualitas Pelayanan tidak berpengaruh signifikan terhadap Kepuasan Pemakai hal ini ditunjukkan dengan nilai $\mathrm{CR}=$ 1,022dan Probabilitas $=0,307$, Kualitas Sistem tidak berpengaruh signifikan terhadap Penggunaan dimana hal ini ditunjukkan dengan nilai $\mathrm{CR}=1,590 \mathrm{dan}$ Probabilitas $=0,112$.

\section{REFERENSI}

[1] Bacon, L.D, 2009. Using AMOS for Structural Equation Modeling im Market Research. Lund Bacon \& Associates.

[2] Delone, W. H., McLean, E.R., 1992. Information System Success: The Quest for the Dependent Variable. Information System Resource Volume 3 No.4 p 60-95.

[3] Delone, W. H., McLean, E.R., 2003. The Delone and McLean Model of Information System Success: A Ten-Year update Journal of Management Information System Volume 19 No.4 p 9-30.

[4] Davis, F.D., 1989. Perceived Ease of Use, and User Acceptance of Information Technology. Management Information System Quality Journal Volume 13 No. 3 p 319-340.
[5] Ghozali, Imam. 2014. Structural Equation Modeling, Metode Alternatif dengan Partial Least Square (PLS). Edisi 4. Semarang: Badan Penerbit Universitas Diponegoro.

[6] Livari, J., 2005. An Empirical Test of the Model of Information System Success. DATA BASE Adv. Inf. Syst, 8-27

[7] M.Ichsan, dkk. Evaluasi Kesuksesan Implementasi OM SPAN Menggunakan Model Delone and Mclean. Vo.1 No.1., April 2017.

[8] Peraturan Direktur Jenderal Pajak Nomor PER26/PJ/2014 tentang Sistem Pembayaran Pajak Secara Elektronik

[9] Peraturan Menteri Keuangan nomor 32/PMK.05/2014 tentang Sistem Penerimaan Negara Secara Elektronik..

[10] Petter, S., Delone, W., McLean, E., 2008. Measuring information system succes: model, dimension, measure, and interrelationships'. European Journal of Information System p 236263.

[11] Purwanto, A., 2007. Rancangan dan Implementasi Model Pemeriksaan Kinerja BPK RI Atas aplikasi e-Government di Pemerintah Daerah: Kabupaten Sragen. Yogyakarta: Universitas Gajah Mada

[12] Jogiyanto. 2007.Model Kesuksesan Sistem Teknologi Informasi. Yoyakarta : Andi.

[13] Jogiyanto.2008.Metodologi Penelitian Sistem Informasi. Yogyakarta : Andi.

[14] Sedera, D., Gable G., Chan T., 2004. A Factor and Structural Equation Analysis of the enterprise systems success measurment model. In Proceedings of the Twenty-Fifth International Conference on Information System $\mathrm{p}$ 449. Washington DS: Associattion for Information System.

[15] Wiyono, G., 2011. Merancang Penelitian Bisnis dengan Alat Analisis SPSS 17.0 dan SmartPLS 2.0. Yogyakarta: UPP STIM YKPN.

[16] Utami, A. W., Samopa, F., 2013. Analisis Kesuksesan Sistem Informasi Akademik (SIAKAD) di Perguruan Tinggi dengan menggunakan D\&M IS Success Model: ITS Surabaya. Jurnal Sistem Informasi Volume 4 No.5 p 294-309.

[17] Sugiyono. 2016. Metode Penelitian Kuantitatif, Kualitatif dan R\&D. Bandung: PT Alfabet. 